https://doi.org/10.5817/NR2021-1-9

\section{Památce docentky Květuše Lepilové}

Jakoby symbolicky na Štědrý den 2020 opustila tento svět doc. PhDr. Květuše Lepilová, CSc. (nar. 9. dubna 1933 v Ostravě), významná slavistka, rusistka a bohemistka, znalkyně hudební kultury, sama hudebnice, správkyně archívu Nadace Františka Lýska, členka Vědecké rady Národní knihovny. Bylo to přirozené: narodila se právě $\mathrm{v}$ rodině sbormistra, hudebního pedagoga Františka Lýska, tvůrce českého sborového zpěvu, jako svébytného umění. Ostatně hudba ji provázela po celý život a působila i na její filologickou orientaci, zejména ve smyslu komunikace uměním, literárním textem, čtením. Činnost doc. Lepilové je tak rozsáhlá, že není možné, aby ji jeden člověk, navíc $\mathrm{v}$ řadě oblastí nekompetentní, obsáhl. Pro mě je především rusistkou, skutečnou filoložkou, která stavěla na nezrušitelném sepětí jazyka a písemnictví, umění a kultury v nejširším slova smyslu.

Maturovala v Brně roku 1951, později složila státní zkoušky na brněnské konzervatoři ze hry na klavír a zpěvu, dále studovala na brněnské univerzitě tehdy klasický obor čeština a ruština a vlastně od počátku se její činnost filoložky týkala komunikace jazykem a literaturou. Po dvacetiletém působení na středních školách v tehdejším Gottwaldově a Olomouci se jejím pracovištěm stala Filozofická fakulta Palackého univerzity
(1973-1990). To už byla doktorkou filozofie, po čase získala i vědeckou hodnost kandidátky věd a stala se docentkou. V roce 1991 už zakládala na nově zřízené Ostravské univerzitě katedru rusistiky. $\mathrm{O}$ to, co pro ni udělala, již dnes málokdo ví: početné grantové projekty, učebnice, konference mladých badatelů, knihy a učební texty směřující k praktickému uplatnění ruštiny, ke komunikaci, textu a kontextu a čtenářství. Od roku 2006 působila externě na Ústavu slavistiky na Filozofické fakultě Masarykovy univerzity, tedy se tak vlastně vrátila na svou alma mater: zde organizovala kurzy pro ruštináře stř̌edních škol a ve spolupráci s kolegy se jí podařilo získat akreditaci MŠMT. Její aktivita nesla s sebou i získávání vyučujících, včetně zahraničních.

Za svou kreativitu byla vysoce hodnocena, mj. stř́ibrnou medailí Univerzity Palackého, medailí Josefa Jungmanna (od České asociace rusistů), obdržela Cenu Bedřicha Smetany aj. Mnoho energie věnovala práci pro Nadaci Františka Lýska: zachování a rozvinutí tvưrčího dědictví svého otce se věnovala s velkým nasazením.

Řada prací, které napsala nebo editovala, byla průkopnická, jako např. Konkretizace uměleckého textu a čtenářská aktivita (1982), Dynamika řečové a literární komunikace (2002), Text, obraz a zvuk (2003), Text a kontext (2003, 2008), Cesty ke čtenářství (2014); vytvořila také několik učebních textů, kulturních a literárních přehledů a poznávacích prací teoreticky i prakticky zaměřených, mj. i na management. Její spolužačka a kamarádka, 
také již zvěčnělá prof. Danuše Kšicová zdůraznila $\mathrm{v}$ jednom jubilejním článku mimo jiné pragmatický aspekt její činnosti, ale to jistě nebylo všechno. Ti, kteří ji alespoň trochu znali, dobře vědí, že její práce byla nesena také obrovskou emocí, nadšením, srdcem. Doc. Lepilová měla ráda lidi, i když její životní cesta profesní nebyla přímočará: z Palackého univerzity musela $v$ roce 1990 odejít, na to se pamatuji velmi dobře a nechci se $\mathrm{k}$ tomu právě zde vracet; podobně i působení a předčasný odchod $\mathrm{v}$ plné síle z Ostravy nebyl projevem solidnosti př́slušných institucí, které se tak připravily o špičkovou odbornici. Když po roce 1990 hledala nové uplatnění a vrátila se vlastně do svého rodiště, byla to ona, kdo nabízela pracovní místa starším i mladým, za něž doslova dýchala: snad si na alespoň někteří vděčně vzpomenou. Dobře se na vše pamatuji a také na různé aktéry: jeden pracovník si po letech nemohl ani vzpomenout, jak se na jejím pracovišti vlastně ocitl. Právě po svém odchodu z Ostravy se na mě obrátila s nabídkou spolupráce, a tak byly položeny základy onoho brněnského projektu, ale ani to nebylo tak hladké, jak se některým dnes zdá: dobře se na to pamatuji. i když se na mnoho věcí už raději zapomnělo; pamět není silnou stránkou naší doby, ani této společnosti. Myslím, že její všestranná činnost nebyla dodnes doceněna. Mám ve zvyku si pamatovat a nezapomínat, zatímco paní docentka se naopak vždy dívala dopředu, uměla odpouštět a zapomínat zlé, i když nevím, jak to vše brala uvnitř̌: $\mathrm{v}$ tom byla její velkorysost, která charakterizuje velké lidi. Rusistika v řadě oblastí její nepřítomnost již nyní postrádá, mezeru, která jejím odchodem vznikla na poli lingvistiky, lingvodidaktiky, literární vědy a výchovy nelze zcela zacelit, nebot kreativní a charakterní lidé jsou nenahraditelní.

Ivo Pospíšil

https://doi.org/10.5817/NR2021-1-10

\section{Brněnské kolokvium - doktorská škola o Ivanu Gončarovovi}

V pořadí již čtvrté (dvakrát Leskov, jednou Dostojevskij) kolokvium se konalo jako mezinárodní doktorská škola pod záštitou děkana FF MU prof. Milana Pola 24. listopadu 2020, tentokrát online, po názvem Ivan Gončarov a evropský klasicismus a neoklasicismus. Doktorandi, resp. aspiranti a jejich učitelé/školitelé z České republiky, Ukrajiny a Ruska využívali různých metodologických postupů (projevily se tu metody literární komparatistiky, generální komparatistiky, genologie, naratologie, recepční estetiky, strukturní analýzy se stopami hermeneutiky aj.) pří zkoumání řady aspektů tvorby autora, která znovu v dnešní době ožívá - stejně jako v anglosaském světě např́iklad podobně založená Jane Austenová (1775-1817; prý právě o ní realistický satirik a humorista Mark Twain, vl. jm. Samuel Langhorne Clemens, $1835-1910$, řekl, že „Every library is good 